\title{
The HR2 Haplotype of Factor V Is not Associated with the Risk of Myocardial Infarction
}

\author{
Carine J. M. Doggen', Marieke C. H. de Visser2, Hans L. Vos², Rogier M. Bertina², \\ Volkert Manger ats $^{3}$, Frits R. Rosendaal ${ }^{1,2}$
}

From the Department of ${ }^{1}$ Clinical Epidemiology, ${ }^{2}$ Hemostasis and Thrombosis Research Center,
3Department of Cardiology, Leiden University Medical Center. The Netherlands

\section{Key words}

Factor V, genetic variation, myocardial infarction, risk

\section{Summary}

The HR2 haplotype of the factor V gene, which contains the histidine to arginine substitution at position 1299 , has been reported to be associated with reduced factor $V$ levels. Because high factor $V$ levels have been found to be associated with an increased risk of myocardial infarction, we examined how the presence of the R2 allele affected the risk of myocardial infarction in the case-control "Study of Myocardial Infarctions Leiden".

Among 560 men with a first myocardial infarction before the age of 70 years, $9.5 \%$ were heterozygous carriers of the $\mathrm{R} 2$ allele. The control group consisted of 646 men, in which $9.9 \%$ were heterozygous and $0.2 \%$ homozygous carriers of the R2 allele. The risk of myocardial infarction in the presence of the $\mathrm{R} 2$ allele was not increased (odds ratio, $0.9 ; 95 \%$ confidence interval 0.6 to 1.4). Exclusion of factor V Leiden carriers did not change this result. The risk was 4.4-fold increased for smokers who carried the R2 allele compared to non-smoking noncarriers. No synergy was found between metabolic risk factors and the presence of the R2 allele.

We conclude that the risk of myocardial infarction for men in the presence of the R2 allele of the His1299Arg polymorphism is neither increased nor decreased.

\section{Introduction}

Coagulation factor $\mathrm{V}$ can be activated by factor Xa or by thrombin. Activated factor $\mathrm{V}$ (factor $\mathrm{Va}$ ) is an essential cofactor of factor $\mathrm{Xa}$ in the conversion of prothrombin to thrombin. Activated protein C (APC) limits the formation of thrombin by proteolytic cleavage of the cofactors Va and VIIIa, and thereby acts as an anticoagulant. Resistance to APC is associated with an increased risk of venous thrombosis $(1,2)$. A few studies reported on the risk of myocardial infarction and found no increased risk (3-5). Most cases of APC-resistance are caused by the presence of factor $\mathrm{V}$ Leiden, a single point mutation in the factor $\mathrm{V}$ gene (Arg506Gln) (6). This mutation is common and increases the risk

Correspondence to: Prof. Dr. F.R. Rosendaal, Clinical Epidemology, Bldg 1 C0-P, Leiden University Medical Center, P.O. Box 9600, 2300 RC Leiden, The Netherlands - Tel.: +31-71-5264037; Fax: +31-71-5248122; E-mail: F.R.Rosendaal@lumc.nl of venous thrombosis considerably $(7,8)$. In contrast, studies on the risk of coronary artery disease in the presence of factor V Leiden are inconsistent, showing a slightly increased risk (9-11) or no excess risk at all $(8,12)$.

Reduced sensitivity for APC not due to factor V Leiden is also associated with an increased risk of venous thrombosis (13). In 1997 a specific haplotype of factor $V$ was reported, which may contribute to an APC-resistant phenotype. This so-called HR2 haplotype contains a histidine to arginine substitution at position 1299 (His1299Arg) in the B-domain of factor V (14). The Arg1299 allele (R2 allele) was found to be associated with partial factor $V$ deficiency in an Italian population (15). In a French study patients with venous thrombosis who carried the $R 2$ allele had significantly lower circulating factor $V$ levels than noncarriers and the risk of venous thrombosis in carriers of the HR2 haplotype was 1.8-fold increased (16). However, in the original study in which the haplotype was reported no increased risk of venous thrombosis was found, nor an association of the R2 allele with reduced factor $V$ levels (14). Factor $V$ activity evaluated in five patients and nine control subjects who carried the R2 allele was considered normal (14). In a study among family members of probands with at least one episode of deep vein thrombosis or pulmonary embolism and an inherited defect (antithrombin, protein C or protein S deficiency, factor V Leiden or the G20210A variation in the prothrombin gene) none of the members carrying only the R2 allele developed venous thrombosis (17). In the "Leiden Thrombophilia Study" (LETS) the risk of deep-vein thrombosis in the presence of this allele was not increased (18). Reduced levels of factor $\mathrm{V}$ antigen in patients as well as in control subjects were found in carriers of the R2 allele. In the LETS we showed the absence of an association between factor $\mathrm{V}$ levels and risk of thrombosis (19). The mechanism by which the R2 allele is associated with reduced factor $V$ levels is not yet known; the His1299Arg polymorphism could be in linkage disequilibrium with another polymorphism in the factor $V$ gene or the variant itself could be responsible for reduced levels. Recently, it has been reported that in carriers of the $\mathrm{R} 2$ allele the ratio of the two isoforms of factor V (factor V1 and factor V2) is shifted in favour of the factor V1 form, which might lead to a higher procoagulant activity $(20,21)$.

It has been suggested that the risk of myocardial infarction in subjects with high levels of factor $V$ activity was higher than in those with low levels (12). Thus, if carriership of the R2 allele is associated with low factor $V$ levels $(15,16,18)$, one might expect carriers to have lower risk of myocardial infarction than non carriers. So far, only one study reported on the risk of arterial thrombosis in the presence of the R2 allele (22); however, the results seem to be in contrast with what we would expect on the basis of the aforementioned hypothesis. We studied the association of the His 1299 Arg polymorphism with myocar- 
Table 1 Genotypes and allele frequencies of factor V His1299Arg (H1299R) polymorphism in patients and control subjects

\begin{tabular}{|c|c|c|c|}
\hline Factor V His1299Arg & $\mathrm{N}$ patients $(\%)$ & $\overline{\mathrm{N}}$ controls (\%) & Odds Ratio $(95 \% \mathrm{CI})$ \\
\hline $\mathrm{H}-\mathrm{H}$ & $507(90.5)$ & $581(89.9)$ & \multirow{5}{*}{$0.9(0.6-1.4)^{\circ}$} \\
\hline$H-R$ & $53(9.5)$ & $64(9.9)$ & \\
\hline R-R & 0 & $1(0.2)$ & \\
\hline frequency $R$ allele $(R 2)$ & $4.7 \%$ & $5.1 \%$ & \\
\hline Tota! & 560 & 646 & \\
\hline \multicolumn{4}{|l|}{$<50$ years } \\
\hline $\mathrm{H}-\mathrm{H}$ & $141(91.6)$ & $147(91.9)$ & 1 \\
\hline H-R & $13(8.4)$ & $12(7.5)$ & \multirow{4}{*}{$1.0(0.5-2.3)^{\circ}$} \\
\hline R-R & 0 & $1(0.6)$ & \\
\hline frequency $R$ allele $(R 2)$ & $4.2 \%$ & $44 \%$ & \\
\hline Total & 154 & 160 & \\
\hline \multicolumn{4}{|l|}{$\geq 50$ years } \\
\hline $\mathrm{H}-\mathrm{H}$ & $366(90.1)$ & $434(89.3)$ & \multirow{5}{*}{$0.9(0.6-1.4)^{\circ}$} \\
\hline H-R & $40(9.9)$ & $52(10.7)$ & \\
\hline $\mathbf{R}-\mathbf{R}$ & 0 & 0 & \\
\hline frequency $R$ allele $(R 2)$ & $4.9 \%$ & $54 \%$ & \\
\hline Total & 406 & 486 & \\
\hline
\end{tabular}

' denotes odds ratio of $\mathrm{H}-\mathrm{R} / \mathrm{R}-\mathrm{R}$ versus $\mathrm{H} / \mathrm{H}$

dial infarction in the population-based case-control "Study of Myocardial Infarctions Leiden" which includes 560 men with a first myocardial infarction and 646 control subjects.

\section{Patients and Methods}

\section{Patients and Control Subjects}

Details of the "Study of Myocardial Infarctions Leiden" have been described elsewhere (10). Briefly, patients were men below the age of 70 with a first myocardial infarction that occurred between January 1990 and January 1996. The control group also consisted of men, frequency matched on age to the patients. They had undergone an orthopedic intervention between January 1990 and May 1996 and had received prophylactic anticoagulants for a short period after the intervention. Both patients and control subjects were born in the Netherlands. The study protocol was approved by the Ethic Committee.

All persons completed a questionnaire concerning the presence of cardiovascular risk factors such as smoking habits, obesity, diabetes, hypertension and hypercholesterolemia. For patients all questions referred to the period before their myocardial infarction. The Quetelet index was derived by dividing weight (kilograms) by squared height (meters ${ }^{2}$ ). Persons were considered obese if their Quetelet index exceeded $30 \mathrm{~kg} / \mathrm{m}^{2}$. Medication use and history of diabetes were ascertained in an interview with control subjects and retrieved from discharge letters for the patients. A person was classified as hypertensive or hypercholesterolemic when he was taking prescription drugs for these conditions. The variables obesity, diabetes, hypertension and hypercholesterolemia were grouped together as "metabolic risk factors".

\section{Blood Collection and DN Analysis}

A morning fasting blood sample was drawn from the antecubital vein in 0.1 volume $0.106 \mathrm{M}$ trisodium citrate using Sarstedt Monovette ${ }^{\circledR}$ tubes. We separated the blood sample into plasma and cells by centrifugation. High molecular weight DNA was extracted from the white blood cells by a salting-out procedure (23). The DNA was stored at $4^{\circ} \mathrm{C}$ until amplification. Analyzable DNA was available for 560 patients and 646 control subjects.

The detection of the His $1299 \mathrm{Arg}$ polymorphism $(4070 \mathrm{~A} \rightarrow \mathrm{G}$ ) (numbering according to Jenny et al. [24]) in the factor $V$ gene was performed by polyme- rase chain reaction (PCR) followed by restriction enzyme digestion. A 1568 bp fragment was amplified with primer A (5'-TGCTCCTTTATCTCCGAGGACC-3') and primer B (5'-CTCTGGAGGAGTTGATGTTTGTCC-3'). The PCR mixture consisted of $4 \mathrm{ng}$ of both oligonucleotides, $250 \mu \mathrm{M}$ of each dNTP, $67 \mathrm{mM}$ Tris-HCl pH 8.8, $6.7 \mathrm{mM} \mathrm{MgCl}_{2}, 10 \mathrm{mM} \beta$-mercaptoethanol, $6.7 \mu \mathrm{M}$ EDTA, $16.6 \mathrm{mM}\left(\mathrm{NH}_{4}\right)_{2} \mathrm{SO}_{4}, 0.5 \mathrm{mg} / \mathrm{ml} \mathrm{BSA}, 0.2$ units AmpliTaq polymerase (Perkin-Elmer) and $10 \%$ DMSO in a total volume of $10 \mu \mathrm{l}$. The reactions were performed in an Amplitron II (Thermolyne). The PCR conditions were as follows: 4 min initial denaturation at $91^{\circ} \mathrm{C}$, followed by 35 cycles of 1 min at $91^{\circ} \mathrm{C}, 1 \mathrm{~min}$ at $63^{\circ} \mathrm{C}$ and $3 \mathrm{~min}$ at $71^{\circ} \mathrm{C}$. A final extension was performed at $71^{\circ} \mathrm{C}$ for $4 \mathrm{~min}$. PCR products were digested by incubation with RsaI (New England Biolabs) at $37^{\circ} \mathrm{C}$ for $2 \mathrm{~h}$. The restriction fragments ( 1438 and 130 bp for the 4070A [His 1299] allele, and 862, 576 and 130 bp for the 4070G allele [Arg 1299, R2 allele]) were separated in 1.3\% agarose gels and visualized after ethidium bromide staining. Genetic analysis of factor V Leiden (1691 G $\rightarrow$ A) status was performed as previously described (6).

\section{Statistical Analysis}

An odds ratio (OR) was calculated as a measure of relative risk. This odds ratio estimates the risk of a myocardial infarction in the presence of the R2 allele relative to the absence of the $\mathrm{R} 2$ allele, the reference category (i. e. noncarriers). A 95\% confidence interval $(95 \% \mathrm{Cl})$ was calculated according to the method of Woolf (25). This interval indicates the range of plausible values for the odds ratio taking chance variation into account. Multiple logistic regression was performed to adjust for age. Confidence intervals for the adjusted odds ratios were calculated using the standard errors of the coefficients estimated by maximum likelihood methods. Means are presented with standard deviation (s.d.).

\section{Results}

The characteristics of all patients and control subjects have been described before (10). The mean age of patients was 56.2 (s.d. 9.0) years and of control subjects 57.3 (s.d. 10.8) years. Risk factors as smoking, obesity, diabetes, hypertension and hypercholesterolemia were more often found in patients than in control subjects, with the most striking contrast in younger persons.

The frequency of the R2 allele was $4.7 \%$ in patients and $5.1 \%$ among control subjects. In 53 out of $560(9.5 \%)$ patients the heterozygous genotype of the His1299Arg variant was detected compared to 64 in 646 control subjects $(9.9 \%)$. Only one homozygous carrier, a control subject 46 years old, was found. The relative risk of myocardial infarction associated with R2 allele carriership was 0.9 (95\% CI $0.6-1.4)$ (Table 1). In the subgroup of 314 men aged less than 50 no increased risk was found [OR $1.0(95 \% \mathrm{CI} 0.5-2.3)$ ]. The risk among persons aged 50 years or more was not increased either [OR 0.9 (95\% CI 0.6 to 1.4)].

Exclusion of carriers of factor V Leiden ( 38 patients and 32 control subjects), resulted in an odds ratio of $0.9(95 \%$ CI $0.6-1.4)$ for R2 carriers compared to non-carriers, again not indicative of an increased risk (Table 2). Among smokers R2-carriers had a 4.4-fold increased risk compared to non-smoking non-carriers. In comparison, smokers without the $\mathrm{R} 2$ allele had a relative risk of about three. The risk among persons with major metabolic risk factors was similar for those with or without the R2 allele, relative to persons without any of these risk factors.

\section{Discussion}

This population-based case-control "Study of Myocardial Infarctions Leiden" shows that the factor V His 1299Arg polymorphism is not 
Table 2 Risk effect of factor $\mathrm{V}$ Leiden, smoking and a metabolic risk factor, without and with the factor V His1299Arg (H1299R) polymorphism

\begin{tabular}{|c|c|c|c|c|}
\hline$\overline{\text { Risk factor }}$ & Factor V His $1299 \mathrm{Arg}$ & N patients (\%*) & $\bar{N}$ controls $\left(\%{ }^{*}\right)$ & Odds Ratio $(95 \% \mathrm{Cl}) \dagger$ \\
\hline \multirow[t]{2}{*}{ No factor $V$ Leiden } & $\mathrm{H}-\mathrm{H}$ & $471(902)$ & $550(896)$ & 1 \\
\hline & $\mathrm{H}-\mathrm{R} / \mathbf{R}-\mathrm{R}$ & $51(98)$ & $64(104)$ & $09(06-14)$ \\
\hline \multirow[t]{2}{*}{ Factor $V$ Lelden } & $\mathrm{H}-\mathrm{H}$ & $36(947)$ & $31(969)$ & $14(08-23)$ \\
\hline & $H-R$ & $2(53)$ & $1\left(\begin{array}{ll}3 & 1\end{array}\right)$ & $23(02-652)$ \\
\hline \multirow[t]{2}{*}{ No smoking } & $\mathrm{H}-\mathrm{H}$ & $191(905)$ & $381(884)$ & 1 \\
\hline & H-R/R-R & $20(95)$ & $50(116)$ & $08(04-14)$ \\
\hline \multirow[t]{2}{*}{ Smokıng } & $\mathrm{H}-\mathrm{H}$ & $316(905)$ & $200(930)$ & $32(24-41)$ \\
\hline & H-R/R-R & $33(95)$ & $15(70)$ & $44(22-87)$ \\
\hline \multirow[t]{2}{*}{ No metabolic risk factor } & $\mathrm{H}-\mathrm{H}$ & $320(901)$ & $403(898)$ & 1 \\
\hline & $\mathrm{H}-\mathrm{R} / \mathrm{R}-\mathrm{R}$ & $35(99)$ & $46(102)$ & $10(06-16)$ \\
\hline \multirow[t]{2}{*}{ Metabolic risk factor } & $\mathrm{H}-\mathrm{H}$ & $187(912)$ & $178(904)$ & $13(10-17)$ \\
\hline & $\mathrm{H}-\mathrm{R} / \mathrm{R}-\mathrm{R}$ & $18(88)$ & $19(96)$ & $12(06-24)$ \\
\hline
\end{tabular}

* percentages are calculated within each stratum of cardiovascular risk factor, 1 e among the persons without factor $V$ Lerden $98 \%$ of patients were carners of the R2 allele of factor V His1299Arg

† reference categones are non- $\mathrm{R} 2$ carriers without the particular risk factor associated with the risk of myocardial infarction. In patients $9.5 \%$ were carrier of the $\mathrm{R} 2$ allele compared to $10.1 \%$ in control subjects, resulting in an odds ratio of $0.9(95 \% \mathrm{Cl} 0.6-1.4)$ indicating no increased risk.

The allele frequency of $5.1 \%$ among our control subjects corresponds with an allele frequency of $4.1 \%$ found in healthy persons from the Dutch "Leiden Thrombophilia Study" (18) and with 5.8\% found among 398 healthy subjects from France (16). Among Italian subjects the frequency seems a little bit higher; allele frequencies of $8.0 \%$ (14) and $7.5 \%$ have been found (15).

The risk of myocardial infarction in the presence of the $\mathrm{R} 2$ allele is not increased in our study, which is in contrast to an Italian case-control study in which a two-fold increased risk of coronary artery disease was found. The prevalence of the $\mathrm{R} 2$ allele was also increased in patients who experienced a myocardial infarction (22). As this study included mainly elderly patients, this might explain the difference with our results. However, when we restricted the analysis to patients between 50 and 70 years of age we did not find an increased risk for carriers of the $\mathrm{R} 2$ allele. The Italian study reported an increased risk for non-smoking carriers, which could not be confirmed in our study.

Our results on the risk of myocardial infarction in the presence of the R2 allele of the His 1299Arg polymorphism are comparable with most, but not all, studies on venous thrombosis. In three different studies on venous thrombosis no increased risk was found at all $(14,18,26)$, while in a study in France an almost two-fold increased risk for carriers of the R2 allele was described (16). The risk of myocardial infarction or venous thrombosis in the presence of a particular mutation involved in the coagulation cascade are often different. For example, results of studies in which the factor $\mathrm{V}$ Leiden mutation was examined as a potential risk factor for myocardial infarction are inconsistent $(8,10-12)$, whereas the risk of venous thrombosis is indisputably increased $(1,8)$.

In several studies the risk of myocardial infarction for a prothrombotic mutation is highly increased in the presence of an established cardiovascular risk factor (10-12). Therefore, we considered the presence of synergy in our present study, i.e. interaction between cardiovascular risk factors and the His1299Arg polymorphism. We found no synergy between metabolic risk factors and the presence of the R2 allele. Although the risk for smokers with the R2 allele was 4.4-fold increased, the confidence intervals in these analyses were too wide to allow any conclusions about synergy.

Only three individuals carried both the factor V Leiden mutation and the R2 allele of the His 1299Arg polymorphism and therefore this study offers little information on the risk for carriers of both variants. In a study of venous thrombosis among 810 family members of probands with at least one venous thromboembolism and an inherited defect, 23 persons carried both variants (17). In these selected family members the relative risk of venous thrombosis associated with factor $\mathrm{V}$ Leiden increased from 4.2 to 10.9 when the $\mathrm{R} 2$ allele was also present. The authors suggested that the prothrombotic action of the R2 allele could be mediated through an enhancement of resistance to APC, synergistic with that caused by factor V Leiden (17). These results could be confirmed in the "Leiden Thrombophilia Study" (18).

Recently, a polymorphism in exon 25 (A6755G) of the factor $V$ gene was detected, causing the substitution of asparagine by glycine at position 2194, at the end of the $\mathrm{C} 2$ domain of factor $V$. It was found to be tightly linked to the R2 allele of the His 1299Arg polymorphism (22). Among 117 heterozygous carriers of the R2 allele in our study all, but two, were also heterozygous carriers of the Gly2194 allele. The homozygous carrier of the $\mathrm{R} 2$ allele was also a homozygous carrier of the Gly2194 allele. These results confirm the tight linkage between the R2 allele and the Gly 2194 allele, as has been described before $(18,21)$.

In conclusion, the risk of myocardial infarction for men in the presence of the R2 allele of the His1299Arg polymorphism is neither increased nor decreased.

\section{Acknowledgements}

The authors wish to thank the cardiologists of the departments of cardiology, Leiden University Medical Center and the general hospttal Draconessenhuis 
Leiden and Dr F J M van der Meer, head Leiden Anticoagulant Clinic for therr kind cooperation We thank Mrs T V Vsser for drawing blood samples and Mrs P Noorduk for performing the DNA analysıs For secretarial and admınıtratıve support we are indebted to Mrs J J Schrejer We also express our gratitude to all individuals who participated in the "Study of Myocardial Infarctions Leiden" This research was supported by the Netherlands Heart Foundation (Grant no 92345) and the Trombosestichting Nederland (Grant no 95 001)

\section{References}

1 Koster T, Rosendaal FR, de Ronde H, Briet E, Vandenbroucke JP, Bertna RM Venous thrombosis due to poor anticoagulant response to activated protein C Leiden Thrombophilia Study Lancet 1993, 342 1503-6

2 Svensson PJ, Dahlback B Resistance to activated protein $C$ as a basis for venous thrombosis N Engl J Med 1994, 330 517-22

3 van der Bom JG, Bots ML, Haverkate F, Slagboom PE, Mejer P, de Jong PTVM, Hofman A, Grobbee DE Reduced response to activated proten C 1s associated with increased risk for cerebrovascular disease Ann Intern Med 1996, 125 265-9

4 Demarmels Biasiuttı F, Merlo C, Furlan M, Sulzer I, Binder BR, Lammle B No assocation of APC resistance with myocardial infarction Blood Coagul Fibrin 1995, 6 456-9

5 Holm J, Zoller B, Berntorp E, Erhardt L, Dahlback B Prevalence of factor $\mathrm{V}$ gene mutation amongst myocardial infarction patients and healthy controls is higher in Sweden than in other countries J Intern Med 1996, $239221-6$

6 Bertina RM, Koeleman BPC, Koster T, Rosendaal FR, Dirven RJ, de Ronde $\mathrm{H}$, van der Velden PA, Rettsma PH Mutation in blood coagulation factor $V$ associated with resistance to activated protein C Nature 1994, $36964-7$

7 Rosendaal FR, Koster T, Vandenbroucke JP, Reitsma PH High risk of thrombosis in patients homozygous for factor $\mathrm{V}$ Letden (activated protein $\mathrm{C}$ resistance) Blood 1995, 85 1504-8

8 Ridker PM, Hennekens CH, Lindpaintner K, Stampfer MJ, Eisenberg PR, Miletich JP Mutation in the gene coding for coagulation factor $V$ and the risk of myocardial infarction, stroke, and venous thrombosis in apparently healthy men N Engl J Med 1995, 332 912-7

9 Marz W, Seydewitz H, Winkelmann B, Chen M, Nauck M, Witt I Muta tion in coagulation factor $\mathrm{V}$ associated with resistance to activated proten $C$ in pattents with coronary artery disease Lancet 1995,345 526-7

10 Doggen CJM, Manger Cats V, Bertna RM, Rosendaal FR Interaction of coagulation defects and cardiovascular risk factors increased risk of myocardial infarction associated with factor $\mathrm{V}$ Leiden or prothrombin 20210A Circulation 1998, 97 1037-41

11 Rosendaal FR, Siscovick DS, Schwartz SM, Beverly RK, Psaty BM, Longstreth WT, Raghunathan TE, Koepsell TD, Reıtsma PH Factor V Leiden (Resistance to actıvated proten $\mathrm{C}$ ) increases the risk of myocardial infarction in young women Blood 1997, 89 2817-21

12 Redondo M, Watzke HH, Stuckı B, Sulzer I, Biasıuttı FD, Binder BR, Furlan M, Lammle B, Wuilemin WA Coagulation factors II, V, VII, and $\mathrm{X}$, prothrombin gene 20210G $>\mathrm{A}$ transition, and factor V Leiden in coronary artery disease high factor $\mathrm{V}$ clottıng activity is an independent risk factor for myocardial infarction Arterioscler Thromb Vasc Biol 1999, 19 10205

13 de Visser MCH, Rosendaal FR, Bertina RM A reduced sensitivity for activated protein $\mathrm{C}$ in the absence of factor $\mathrm{V}$ Letden increases the risk of venous thrombosis Blood 1999, 93 1271-6

14 Bernardı F, Faını EM, Castoldı E, Lunghı B, Castaman G, Sacchı E, Mannuccı PM A factor $\mathrm{V}$ genetıc component differing from factor $\mathrm{V}$ R506Q contributes to the activated protenn $\mathrm{C}$ resistance phenotype Blood $1997,90 \quad 1552-7$

15 Lunghı B, Iacoviello L, Gemmatı D, Dilası MG, Castoldı E, P1notı M, Castaman G, Redaellı R, Marıanı G, Marchettı G, Bernardı F Detectıon of new polymorphic markers in the factor $\mathrm{V}$ gene association with factor $\mathrm{V}$ levels in plasma Thromb Haemost 1996, 75 45-8

16 Alhenc-Gelas M, Nicaud V, Gandrille S, van Dieden P, Amıral J, Aubry ML, Fressinger JN, Emmerich J, Aiach M The factor V gene A4070G mutation and the risk of venous thrombosis Thromb Haemost 1999, 81 1937

17 Faronı EM, Franchı F, Bucciarellı P, Margaglıone M, de Stefano V, Casta man G, Finazzl G, Mannucc PM Conheritance of the HR2 haplotype in the factor $\mathrm{V}$ gene confers an increased risk of venous thromboembolism to carriers of factor V R.506Q (factor V Leiden) Blood 1999, 94 3062-6

18 de Visser MCH, Guasch JF, Kamphuisen PW, Vos HL, Rosendaal FR, Bertina RM The HR2 haplotype of factor $V$ Effects on factor V levels, normalized activated protein $\mathrm{C}$ sensitivity ratios and the risk of venous thrombosis Thromb Haemost 2000, 83 577-82

19 Kamphusen PW, Rosendaal FR, Erkenboom JCJ, Bos R, Bertına RM Factor $\mathrm{V}$ antigen levels and venous thrombosis risk profile, interaction with factor $\mathrm{V}$ Leiden and relation with factor VIII antigen levels Arte noscler Thromb Vasc Biol 2000, 20 1382-6

20 Hoekema L, Nicolaes GA, Hemker HC, Tans G, Rosing J Human factor Val and factor Va2 properties in the procoagulant and anticoagulant pathways Bıchemistry 1997, 36 3331-5

21 Castoldı E, Rosing J, Grrellı D, Hoekema L, Lunghı B, Mıngozzı F, Ferraresı P, Friso S, Corrocher R, Tans G, Bernardi F Mutations in the R2 FV gene affect the ratio between the two FV soforms in plasma Thromb Haemost 2000, 833625

22 Castoldı E, Rosing J, Lunghı B, Hoekema L, Gırelı D, Mıngozzı F, Ferraresı P, Friso S, Corrocher R, Tans G, Bernard $F$ Factor V gene muta tions ( $R 2$ gene) are associated with coronary artery disease in elderly people Thromb Haemost 1999, Suppl 509

23 Miler SA, Dykes DD, Polesky HF A sımple saltıng out procedure for extracting DNA from human nucleated cells Nucleic Acids Res 1988, 16 1215

24 Jenny RJ, Pittman DD, Toole JJ, Kriz RW, Aldape RA, Hewick RM, Kaufman RJ, Mann KG Complete cDNA and derived amıno acıd sequen ce of human factor V Proc Natl Acad Scı USA 1987, 84484650

25 Woolf B On estımating the relation between blood group and disease Ann Hum Genet 1955, 19 251-3

26 Luddington R, Jackson A, Pannerselvam S, Brown K, Baglın T The factor $V$ HR2 haplotype risk of venous thromboembolsm, factor $V$ levels and resistance to actuvated protein C Thromb Haemost 2000, 83 204-8

Received February 28, 2000 Accepted after revision May 31, 2000 